Vladimir Ilich Fedyukov' ${ }^{1}$ Tatiana Alexandrovna Makarieva², Ekaterina Yurevna Saldaeva ${ }^{1}$, Ekaterina Mikhailovna Tsvetkova ${ }^{1}$

\title{
Biophysical Bases for Vibroacoustic Diagnostics of Standing Sounding Wood
}

\section{Biofizikalni temelji vibroakustične dijagnostike zvučnosti rastućeg stabla}

\author{
Preliminary paper • Prethodno priopćenje \\ Received-prispjelo: 20. 2. 2015. \\ Accepted-prihvaćeno: 5. 5. 2016. \\ UDK: $630 * 812.12 ; 630 * 812.42$ \\ doi:10.5552/drind.2016.1514
}

\begin{abstract}
At the turn of the third millennium, scientists and experts of many countries are still trying to puzzle out 'the mystery of Stradivari', using for this purpose advanced technological solutions in the fields of physics, mathematics, chemistry, biology, etc. It has been undoubtedly proved that one of the basic secrets of the great master's violin sounding is in the recognition of the proper material. Unfortunately, Stradivari, Amati, Guarneri and other great representatives of the Old Italian school did not leave any hints, but it has been recorded that they selected wood for the string-plate, the main sounding part of a violin, by tapping, and they designed an instrument judging from the 'sonority' factors known to them only. Using modern scientific terms, it is possible to ascertain that it was the professional skill of the master to decode the percussion-acoustic response of the source material that predetermined the quality of the product. The results of the work done cannot claim to disclose any secrets in the field. For this purpose, significant complex research is necessary, both fundamental and applied, integrating the efforts of scientists and experts in different areas: physicists, acousticians, wood scientists, foresters and, the main thing, the recognized masters in the sphere of manufacturing corresponding musical instruments. This paper presents the first results of implementing the technique based on the excitation of fluctuations of a trunk by a special shock device with further recording, decoding and analyzing acoustic response, matching it with the conditions of growth and general morphology of a tree, i.e. its size, crown form and length, trunk habit, etc. As such a work does not have any analogues and, consequently, there is no 'acoustic standard' of a sounding tree for the moment, the data obtained were analyzed in accordance with general provisions of acoustic diagnostics. Thus, the basic acoustic parameters accepted are vibrating activity, power consumption of spectral characteristics, amount of resonance peaks, vibration absorbing and damping, frequency distribution of a spectrum.
\end{abstract}

Key words: spruce tree, sounding wood, shock device, acoustic response, impedance, vibration absorbing, frequency, histogram

SAŽETAK • Na početku trećeg tisućljeća znanstvenici i stručnjaci iz mnogih zemalja još pokušavaju odgonetnuti „,tajnu Stradivarija” koristeći se naprednim tehnološkim rješenjima iz područja fizike, matematike, kemije, biologije i drugih znanosti. Nepobitno je dokazano da je jedna od osnovnih tajni velikog majstora violina umijeće prepoznavanja odgovarajućeg materijala za izradu violina. Nažalost, Stradivari, Amati, Guarneri i drugi poznati predstavnici stare talijanske škole nisu ostavili nikakve naputke o izboru najboljeg materijala. No povijesna je činjenica da su oni drvo za gudačku ploču, glavni zvučni dio violine, odabirali kuckanjem po površini drva i dizajnirali instrument izabirući materijal prema zvučnosti, a obilježja dobre zvučnosti bila su poznata samo njima.

\footnotetext{
${ }^{1}$ Authors are professor, associate professor and senior teacher at the Forest-Engineering Faculty, Volga State University of Technology, Yoshkar-Ola, Russia. ${ }^{2}$ Author is acoustic scientist, $\mathrm{PhD}$ candidate of sciences in engineering, Saint-Petersburg.

Autori su profesor, izvanredni profesor i predavač Fakulteta šumarskog inženjerstva, Državno tehnološko sveučilište Volga, Yoshkar-Ola, Russia. ${ }^{2}$ Autorica je akustičarka, doktorandica, Saint-Petersburg.
} 
Suvremenim znanstvenim rječnikom može se reći da su ti veliki majstori imali profesionalnu vještinu dekodiranja akustičnog odgovora izvornog materijala koji je unaprijed određivao kvalitetu proizvoda. Na temelju rezultata provedenih istraživanja ne može se tvrditi da su otkrivene sve tajne tog umijeća. Za tu bi svrhu bilo potrebno provesti obuhvatna i kompleksna istraživanja, i temeljna i primijenjena, integrirajući napore znanstvenika i stručnjaka s različitih područja: fizičara, akustičara, drvnih tehnologa, šumara $i$, što je najvažnije, priznatih majstora iz područja proizvodnje odgovarajućih glazbenih instrumenata. U radu su prikazani prvi rezultati primjene tehnike mjerenja koja se temelji na pobuđivanju vibracija debla posebnim uređajem, uz snimanje, dekodiranje i analizu akustičnog odgovora te uzimanjem u obzir uvjeta rasta i općih morfoloških obilježja stabla, odnosno njegove veličine, oblika krošnje i dužine, oblika debla i sl. S obzirom na to da ne postoje analogna istraživanja, odnosno da još ne postoji ,,akustični standard” za zvučnost drva, dobiveni su podaci analizirani u skladu s općim odredbama akustične dijagnostike. Prihvaćeni osnovni akustični parametri jesu vibracije, potrošnja energije i spektralna svojstva zvuka, broj rezonantnih pikova, apsorpcija i prigušenje vibracija te raspodjela frekvencija spektra.

Ključne riječi: drvo smreke, zvučnost drva, pobudni uređaj, akustični odziv, impedancija, apsorpcija vibracija, frekvencije, histogram

\section{INTRODUCTION}

\section{UVOD}

It is well-known that existing techniques for quality diagnostics of so-called sounding wood for manufacturing string-plates, the main sounding part of a violin, are based on laboratory study of timber assortments.

Meanwhile, sharp practical necessity for the development of nondestructive ways of 'sounding' trees selection long before their felling through dendroacoustic diagnostics has long been overdue. This would offer real opportunities not only for rational target use of the available stocks of this highly valuable natural raw material, but, the main thing, preserve the gene resources of the sounding spruce trees and some other species by revealing unique specimens and their reproducing on specialized plantations.

For achieving this goal, the 'shock-acoustic' technique, which is a relatively new one for this field but widely used in others, can play a significant role.

As far as wood represents a product of biological development and essentially differs from other materials, e.g., it displays anisotropy of physical-mechanical and acoustic properties, complex biophysical research of trees directly in forest environment is necessary for working out the technique given.

\section{THEORETICAL BACKGROUND 2. TEORIJSKA OSNOVA}

The speed of acoustic wave distribution and physical-mechanical characteristics of any material are in close correlation, which is proved by the results of numerous research works; however, it is necessary to bear in mind that these studies are basically devoted to isotropic bodies.

One of the widely-used methods here is ultrasonic pulse technique implemented to control the properties of metal, concrete and other materials (Gladylin, 2000; Aleshchenko et al., 2001; Yermolov and Lunger, 2004). It is based on the measurement of a delay of the pulse radiated and received after passing the material layer. The characteristic features of the method are operational efficiency and simplicity.
Wood, as a product of biological origin, represents anisotropic matter having unequal parameters of physical-mechanical properties in different directions relative to the fibers, not excluding the acoustic ones. In comparison with an isotropic body, this circumstance essentially complicates carrying out the acoustic measurements of this material with standard methods and limits their practical application.

Even more obstacles arise when introducing nondestructive diagnostics of acoustic quality of standing wood, e.g., when selecting sounding wood for manufacturing a string-plate, the main sounding part of many musical instruments.

First of all, in this case there is no opportunity to carry out longitudinal measurements of wood without cutting a tree and manufacturing standard samples, e.g., bars with dimensions of 200x200x300 mm according to National State Standard GOST 16483.21 'Methods of sampling for defining physical-mechanical properties after technological processing', the national standard of Russia.

Secondly, the processes of longitudinal or crosssection fluctuations in wood are much more complex than in isotropic bodies. Therefore, the theory of elastic waves for the description of acoustic properties of wood is applicable in the limited number of cases, predominantly for the samples in the form of long rods. In other words, to exclude scale factor, the phenomena of interference and dispersion (in this case, in conditions of ultrasonic wave propagation in a rod), it is necessary to observe the following ratio (Goldsteins, 1975; Fedyukov and Makaryeva, 1993):

where

$$
L \geq 1.51, \quad \text { a } \lambda=C / f
$$

$L$ - linear dimensions of the sample, $\mathrm{m}$;

$\lambda$ - wave length, $\mathrm{m}$;

$C$ - speed of ultrasonic wave propagation in wood, $\mathrm{m} / \mathrm{s}$; $f$ - signal working frequency, $\mathrm{Hz}$.

As the correlation of the tree diameter and its height does not meet these requirements, the application of ultrasonic pulse methods for cross-section (diagonal) measurements of trunk wood may cause significant errors.

For nondestructive diagnostics of resonance properties of standing trees, two basic study lines are 
more realistic and preferable: visual-biomorphological and dendro-acoustic.

The former, visual-biomorphological line, is based on the correlation of wood quality and hereditary genetic features of a given tree species, habitat conditions (including geographical region) and silviculturalforest inventory parameters of forest stands. Together, they form corresponding properties of wood, which can be ascertained according to external biomorphological attributes of a tree: the crown form and length, the trunk habit, the bark color and structure, cones and seed scales, color and form, etc.

However, it is important to bear in mind that such an indirect method of diagnostics is not deprived of the elements of subjectivity; therefore, it cannot always provide high accuracy of forecasting of wood technical quality.

The latter line, dendro-acoustic one, can include several techniques. For example, the trial-acoustic method is more objective in comparison with the visual-biomorphological one. It is based on taking a wood cross-section radial core-sample about $4 \mathrm{~mm}$ in diameter from a tree trunk and studying its physical-mechanical properties, including the resonance ones (Fedyukov and Makaryeva, 1995; Bucur, 1983).

Not belittling the accomplishments of this way of revealing resonance properties of standing wood, it is expedient to remember an ancient way of quality wood selection in a forest by tapping trees. Using modern scientific terminology, it is possible to consider a vibroimpulsive method of express diagnostics of body wood technical quality under the acoustic response.

The purpose of the present work is to reveal the opportunity of implementation of a vibroimpulsive method for nondestructive estimation of acoustic quality of standing wood as potential resonance raw material.

\section{MATERIAL AND METHODS}

\section{MATERIJAL I METODE}

To perform research in forest environment, the devices manufactured by well-known firms "Robotron" (Germany) and "Bruel \& Kjaer" (Denmark) were used: 00017- and 00023- type pulse sound meters, 02060-type recorder of a signal level, 7004-type measuring tape recorder, 3348-type real time spectrum analyzer, 4367-type accelerometer, 8200-type sensor.

A special hammer was designed to make a tree vibrate, and a batch production accumulator was used as an energy source.

Before analyzing the results obtained, let us consider the key diagrams of the devices and the acoustic parameters studied.

The shock device is a hammer, the head of which bears a built-in 8200-type force sensor and 4367-type accelerometer. The bar handle of the hammer is freely held by the fixing spindle, which makes it possible to attach the shock device to a tree without any efforts (Fig. 1).

The hammer creates mechanical impact on a tree after being lowered from a certain height due to reali-

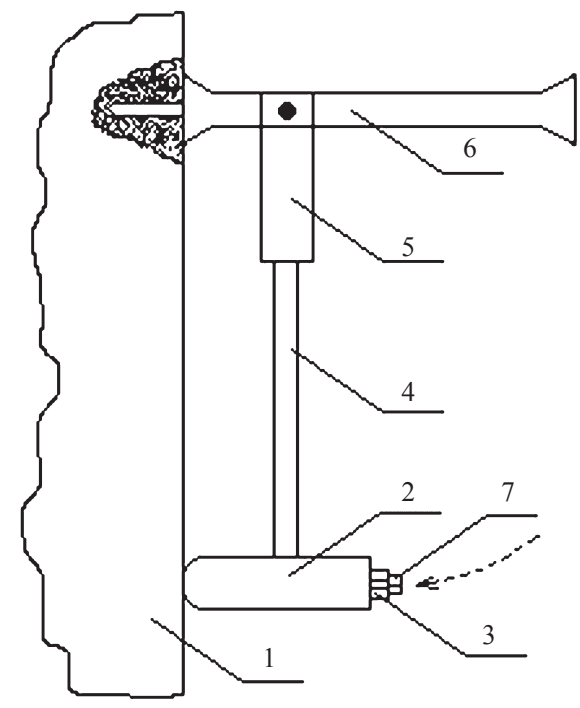

Figure 1 Shock device key diagram (1 - wood, 2 - hammer head, 3 - force sensor, 4 - bar handle, 5 - axle, 6 - fixing spindle, 7 - accelerometer)

Slika 1. Shema pobudnog uređaja ( 1 - drvo, 2 - glava čekića, 3 - senzor sile, 4 - ručka, 5 - osovina, 6 učvršćenje vretena, 7 - akcelerometar)

zation of potential energy (Fig. 2). The force with which the hammer strikes the tree is measured by the 8200-type force sensor, and the acoustic signal of trunk excitation is registered by 4367-type accelerometer.

To define the acoustic characteristics of a standing tree, specifically, point impedance, it is necessary to move over from the level of signals expressed in $\mathrm{dB}$ for force $F$ and speed $C$ to absolute values of these parameters. With that in mind, calibration of the hammer by a standard technique with impactor was carried out in laboratory conditions for force $F$. As a result, corresponding calibrating curve dependences of force $F, \mathrm{~Hz}$ on the size of sound meter readings values $A, \mathrm{~dB}$ were received.

To translate the values of speed $C, \mathrm{~dB}$, into absolute values, $\mathrm{m} / \mathrm{s}$, reference values of GOST 12.1.01278. 'Vibration' were used.

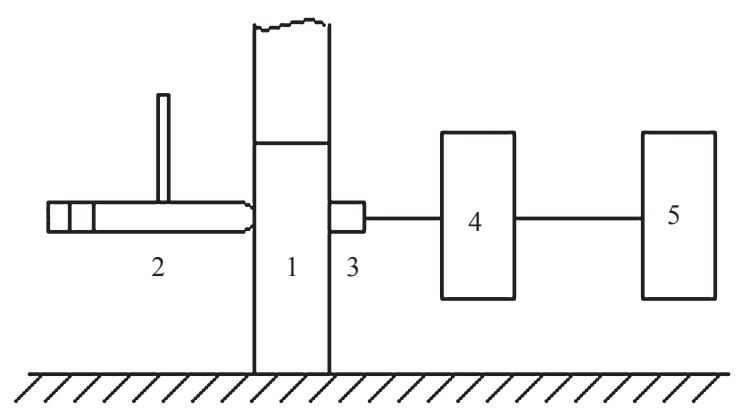

Figure 2 Key diagram of vibroacoustic response taking and recording ( 1 - tree trunk, 2 - hammer, 3 - 4367-type accelerometer, 4 - 00023-type sound meter, 5 -02060-type recorder of a signal level (or 7004-type measuring tape recorder))

Slika 2. Dijagram snimanja vibroakustičnog odgovora (1 - trupac, 2 - čekić, 3 - akcelerometar, tip 4367, 4 - zvukomjer, tip 00023, 5 - snimač razine signala, tip 02060 ili kasetofon, tip 7004) 
The time of contact of the hammer and the tree studied was defined in laboratory environment on the samples of room-dry wood $t$, and at the humidity close to its newly felled condition $t_{2}$. The time was defined according to the width of a signal duration at the amplitude level of 0.7 . The following values were received: $t_{1}=0.53 \mathrm{~m} / \mathrm{s} ; t_{2}=0.85 \mathrm{~m} / \mathrm{s}$.

Vibroacoustic response. Taking and recording the vibroacoustic response of tree $A(\mathrm{~dB})$ representing its reaction to impact disturbance was made in $1 / 3$ octave band according to the following key diagram (Fig. 2).

The impact was made in the debarked point at breast height on one side of a trunk, and the accelerometer-piezoelectric detector connected with sound meter was fixed on the opposite side. Recording of the acoustic response was performed with the help of the signal level recorder or measuring tape recorder through corresponding circuit connection to the sound meter depending on the goal.

The signal level recorder was used to record the changes of the response on the tape with the impacts at certain time. The speed of recording was $30 \mathrm{~mm} / \mathrm{s}$.

The measuring tape recorder recorded a signal from piezoelectric detector with the view of spectral analysis of vibroacoustic response in real time. It was impossible to register the acoustic response through the tape recorder directly due to loud noise similar to the one from harvesting machinery and other sources.

The signal from the tape recorder was further recorded on a ring of magnetic tape and analyzed with a spectrometer in real time. At repeated recurrence of the signal studied, the maximum spectrum was represent- ed on the screen of a spectrometer. The frequency and amplitude of resonance peaks were defined with the help of a control line in the digital image.

The analysis of vibroacoustic spectra of standing trees was made in the ranges of $1 \mathrm{kHz} ; 2 \mathrm{kHz} ; 10 \mathrm{kHz}$.

Note that the relative size of signal vibration acceleration level registered is the key parameter of vibroacoustic response measurement:

$$
A(d B)=20 \cdot \log \frac{a_{\text {meas }}}{a_{0}}
$$

where

$a_{\text {meas }}-$ acceleration measured, $\mathrm{m} / \mathrm{s}^{2}$;

$a_{0}$ - threshold value of acceleration equal to $10^{-3} \mathrm{~m} / \mathrm{s}^{2}$.

Sample data $A(\mathrm{~dB})$ for a certain tree depending on the frequency of $1 / 3$ octave band are given in Tab. 2 .

Vibroacoustic absorption. The work was carried out according to the conventional vibroacoustic absorption measurement technique and differed from the research of acoustic response in the measuring system circuit (Fig. 3).

The level of signals from the hammer side and the opposite side of a tree were registered simultaneously. Conventional absorption $\Delta B(\mathrm{~dB})$ was defined as difference between the values of initial signal $B^{1}(\mathrm{~dB})$ and final signal $\mathrm{B}^{2}(\mathrm{~dB})$ :

$$
\Delta \hat{A}=B^{1}-B^{2}
$$

Dividing the value received with the value of a tree diameter, $\mathrm{m}$, conventional vibroacoustic absorption per unit length was estimated, i.e. $\Delta B, d B / \mathrm{m}$.

'Point impedance' is known to be an integral value defined as

$$
Z=\frac{F}{C}
$$

\begin{tabular}{|c|c|c|c|c|c|c|c|}
\hline $\begin{array}{c}\text { Tree index } \\
\text { number } \\
\text { Broj } i \\
\text { oznaka } \\
\text { stabla }\end{array}$ & $\begin{array}{c}\text { Height } \\
\text { Visina } \\
\mathrm{m}\end{array}$ & $\begin{array}{c}\text { Breast height } \\
\text { diameter } \\
\text { Promjer na } \\
\text { prsnoj visini }\end{array}$ & $\begin{array}{c}\text { Diameter } \\
\text { at height } \\
\mathbf{0 . 2} \boldsymbol{H} \\
\text { Promjer na } \\
\text { visini } 0,2 \mathrm{H}\end{array}$ & $\begin{array}{c}\text { Diameter } \\
\text { at height } \\
\mathbf{0 . 5} \boldsymbol{H} \\
\text { Promjer na } \\
\text { visini } 0,5 \mathrm{H}\end{array}$ & \begin{tabular}{|c|} 
Diameter at \\
height \\
0.7 $\boldsymbol{H}$ \\
Promjer na \\
visini $0,7 \mathrm{H}$
\end{tabular} & $\begin{array}{l}\text { Height to the first } \\
\text { branch alive } \\
\text { Visina do prve žive } \\
\text { grane } \\
\text { m }\end{array}$ & $\begin{array}{l}\text { Alive crown length, } \\
\% \text { of the total trunk } \\
\text { length } \\
\text { Duljina žive krošnje, } \\
\text { postotak ukupne } \\
\text { duljine debla }\end{array}$ \\
\hline A1 & 22.8 & 28 & 25 & 19 & 12 & 7.9 & 63 \\
\hline $\mathrm{A} 2$ & 24.8 & 41 & 36 & 24 & 14 & 8.9 & 64 \\
\hline A4 & 23.0 & 31 & 28 & 22 & 14 & 9.0 & 61 \\
\hline A5 & 23.5 & 32 & 27 & 22 & 16 & 9.1 & 61 \\
\hline A9 & 23.53 & 32 & 28 & 22 & 14 & 8.4 & 64 \\
\hline D1 & 28.0 & 39 & 35 & 27 & 20 & 8.4 & 70 \\
\hline D3 & 26.0 & 36 & 33 & 27 & 20 & 10.0 & 61 \\
\hline D7 & 25.4 & 36 & 33 & 28 & 20 & 7.6 & 70 \\
\hline D9 & 26.2 & 34 & 31 & 24 & 20 & 10.3 & 61 \\
\hline D14 & 30.0 & 42 & 38 & 31 & 15 & 5.9 & 80 \\
\hline D17 & 26.0 & 33 & 29 & 20 & 17 & 7.4 & 71 \\
\hline D18 & 25.7 & 33 & 29 & 23 & 13 & 8.2 & 68 \\
\hline D19 & 25.6 & 31 & 26 & 22 & 14 & 12.5 & 51 \\
\hline B1 & 34.0 & 58 & 51 & 41 & 36 & 6.8 & 80 \\
\hline B2 & 26.8 & 40 & 34 & 26 & 21 & 9.4 & 64 \\
\hline B3 & 33.6 & 50 & 46 & 37 & 32 & 7.2 & 76 \\
\hline B6 & 28.9 & 43 & 37 & 32 & 23 & 19.4 & 67 \\
\hline B8 & 26.0 & 34 & 27 & 21 & 14 & 9.5 & 63 \\
\hline B10 & 28.0 & 33 & 29 & 23 & 18 & 8.5 & 69 \\
\hline
\end{tabular}

Table 1 Sample tree characteristics according to the results of measurement of standing and felled trees

Tablica 1. Obilježja uzoraka stabala prema rezultatima mjerenja dubećih i posječenih stabala 


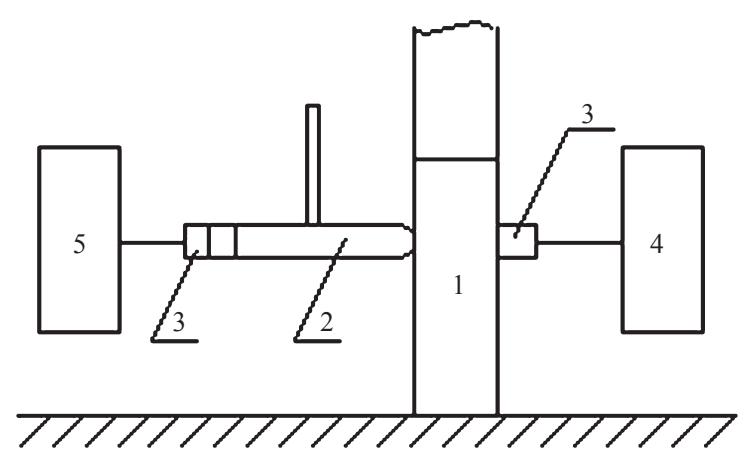

Figure 3 Key diagram of vibroabsorbtion measurement $(1$ - tree trunk, 2 - hammer, 3 - accelerometer, 4 -00023-type sound meter, 5 -00017-type sound meter) Slika 3. Dijagram mjerenja apsorpcije vibracija $(1-$ deblo, 2 - čekić, 3 - akcelerometar, 4 - zvukomjer, tip 00023, 5 - zvukomjer, tip 00017)

where

$Z$ - acoustic impedance, $\mathrm{H} \cdot \mathrm{s} / \mathrm{m}$;

$F$ - effective force, $\mathrm{H}$;

$C$ - object speed created by this force, $\mathrm{m} / \mathrm{s}$.

Impedance constituents were measured according to the diagram (Fig. 4).

\section{RESULTS AND DISCUSSION}

\section{REZULTATI I RASPRAVA}

The method of vibroacoustic diagnostics of wood quality was tested on 19 spruce trees at the age of 200250 years growing in northern parts of the Kirov region on the territory of Murashinsky timber enterprise. The diameter of tree trunks at breath height was $0.28-0.58$ $\mathrm{m}$, and their height was 22.8-32.0 m.

Test trees differed by biomorphological attributes, e.g, branching type and crown form (length), habit (diameter change along the trunk), bark structure, cones and, especially, their seed scales size. The geographical region under consideration is a zone of introgressive hybridization of the species, therefore aboriginal clones of Norway spruce (Picea abies) and Siberian spruce (Picea obovata) in their pure form can be found rather seldom there. More often, their intermediate hybrid forms can be come across.

The trial areas, conditionally labeled A, D and B, were laid out in bilberry scrub forests differing from each other in productivity:

A - III yield class, rather low relief with attributes of humidifying (rather bad conditions);

D - II yield class, upland (average conditions);

B - I yield class, smooth hill slope (the best conditions).

The basic characteristics of sample trees on trial areas A, D and B are given in Tab. 1.

As shown in Tab.1, sample trees have high crown and, for this species, a rather big length of trunk without branches. Such a choice of trees is made purposefully in order to get a maximum yield of sonorous assortments used for manufacturing musical instruments, in particular, kantele, after calibration and laboratory testing by standard methods.

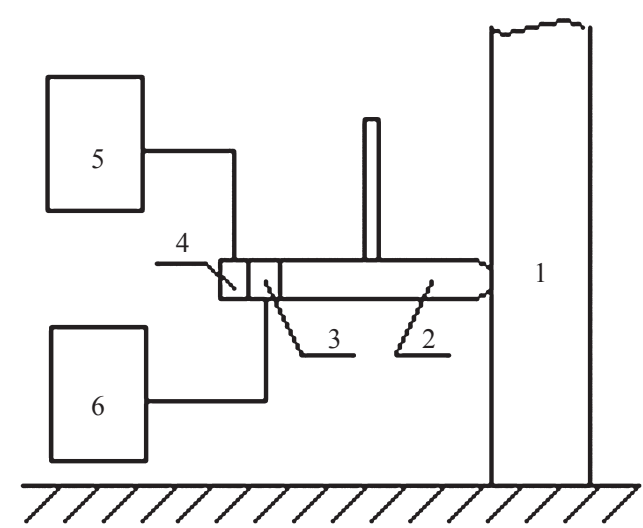

Figure 4 Impedance measurement key diagram $(1-$ tree trunk; 2 - hammer; 3 - 8200-type force sensor; 4 - 4367type accelerometer; 5 - 00017-type sound meter; 6 - 0023type sound meter)

Slika 4. Dijagram mjerenja impedancije ( 1 - deblo, 2 - čekić, 3 - senzor sile, tip 8200, 4 - akcelerometar, tip 4367, 5 - zvukomjer, tip 00017, 6 - zvukomjer, tip 0023)

The following results of vibroacoustic diagnostics of the trees on the specified trial plots were received.

According to vibroacoustic response in $1 / 3$ octave bands, judging from the average value, the trees from trial plots A (5 pieces), D ( 9 pieces) and B (6 pieces) appeared to be the best ones.

The advantage of group A trees consisted in the increase in the level of the response in low-frequency area and displacement of a maximum towards high frequencies. However, being compared individually in view of this attribute, the trees from sample plots other than plot A appeared to stand out as well; those were samples A2, D19, and B10 (Tab. 2).

For better perception and comparison of the data obtained, the frequency dependence of the response value is presented in the form of histogram, passing from relative units to absolute ones. According to the form of the histogram, the vibroacoustic response of the trees studied can be divided into 4 types having the following attributes:

$\mathrm{T}_{1}$ - presence of resonance peaks in the low frequency region comparable in amplitude with the main peak in the range of $600+800 \mathrm{~Hz}$; it includes trees A2, A5, D18 and B10;

$\mathrm{T}_{2}$ - high frequency peak prevails in the frequency range of $2000+3000 \mathrm{~Hz}$, low frequency peak is not expressed; trees D19 and B2;

$\mathrm{T}_{3}$ - additional resonance is absent in both low frequency and high frequency regions; trees D2, D3, D6, D14, B1 and B3;

$\mathrm{T}_{4}$ - three resonance peaks comparable in amplitude are present; trees A1, A4, B2 and B10.

On the example of typical samples A2, D19, B1 and B10 strongly differing in habit and other biomorphological parameters, histograms of the acoustic response of the above specified types are given below (Fig. 5). 
Table 2 Values of acoustic response of the trees $(A, \mathrm{~dB})$ at various frequencies in $1 / 3$ octave filters

Tablica 2. Vrijednosti akustičnog odgovora stabala $(A, \mathrm{~dB})$ pri različitim frekvencijama $1 / 3$ oktave

\begin{tabular}{|c|c|c|c|c|c|c|}
\hline \multirow[t]{2}{*}{$\begin{array}{l}\text { Frequency, } \mathbf{H z} \\
\text { Frekvencija, } \mathrm{Hz}\end{array}$} & \multicolumn{3}{|c|}{$\begin{array}{l}\text { Mean values of acoustic response of the samples } \\
\text { Srednje vrijednosti akustičnog odgovora uzoraka }\end{array}$} & \multicolumn{3}{|c|}{$\begin{array}{l}\text { Best trees for acoustic response } \\
\text { Akustični odgovor najboljih uzoraka }\end{array}$} \\
\hline & $\mathrm{A}$ & $\mathrm{D}$ & $\mathrm{B}$ & $\mathrm{A} 2$ & D19 & $\mathrm{B} 10$ \\
\hline 31.5 & 49.8 & 49.7 & 42.2 & 55.5 & 57.5 & 58.0 \\
\hline 40 & 53.1 & 50.6 & 42.0 & 55.0 & 58.5 & 54.0 \\
\hline 50 & 54.6 & 50.6 & 45.4 & 53.5 & 60.0 & 55.0 \\
\hline 63 & 53.8 & 49.4 & 44.0 & 53.0 & 59.0 & 49.5 \\
\hline 80 & 54.1 & 50.3 & 44.3 & 55.0 & 57.0 & 48.0 \\
\hline 100 & 57.0 & 54.3 & 44.1 & 57.0 & 55.0 & 49.0 \\
\hline 125 & 58.0 & 55.7 & 49.4 & 56.0 & 50.5 & 54.0 \\
\hline 160 & 57.8 & 58.2 & 51.0 & 55.0 & 59.0 & 62.0 \\
\hline 200 & 55.6 & 54.6 & 47.1 & 50.0 & 55.0 & 58.0 \\
\hline 250 & 56.4 & 53.8 & 51.0 & 58.0 & 56.0 & 58.5 \\
\hline 315 & 58.9 & 60.6 & 56.4 & 60.0 & 63.5 & 60.0 \\
\hline 400 & 62.7 & 62.9 & 62.3 & 62.0 & 66.0 & 62.0 \\
\hline 500 & 71.8 & 68.8 & 73.2 & 75.0 & 75.0 & 70.0 \\
\hline 630 & 77.6 & 78.4 & 77.2 & 80.0 & 74.0 & 76.0 \\
\hline 800 & 84.4 & 82.8 & 80.9 & 84.0 & 81.5 & 87.0 \\
\hline 1000 & 79.7 & 77.7 & 76.8 & 82.5 & 76.0 & 78.0 \\
\hline 1050 & 73.4 & 77.9 & 73.4 & 74.5 & 77.0 & 72.0 \\
\hline 1600 & 76.9 & 77.0 & 73.2 & 72.0 & 83.0 & 72.0 \\
\hline 2000 & 78.8 & 77.1 & 75.0 & 79.5 & 83.5 & 80.0 \\
\hline 2500 & 77.7 & 74.3 & 72.3 & 72.0 & 85.5 & 77.0 \\
\hline 3150 & 79.2 & 76.0 & 76.1 & 82.0 & 84.5 & 78.5 \\
\hline 4000 & 75.3 & 73.6 & 72.9 & 81.5 & 65.0 & 74.0 \\
\hline 5000 & 68.4 & 75.6 & 64.5 & 68.5 & 69.5 & 67.0 \\
\hline 6300 & 62.9 & 65.3 & 62.6 & 66.0 & 67.5 & 61.7 \\
\hline 8000 & 62.7 & 59.2 & 58.1 & 62.5 & 67.5 & 62.0 \\
\hline $\begin{array}{c}\text { Mean value } \\
\text { Srednja vrijednost }\end{array}$ & 65.6 & 64.6 & 60.6 & 66.0 & 67.5 & 64.9 \\
\hline
\end{tabular}

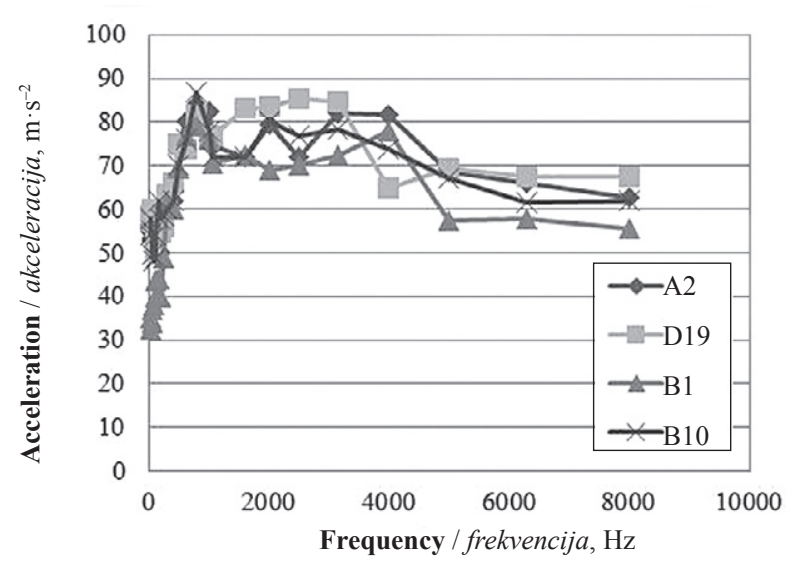

Figure 5 Acoustic response histograms: 1 - A2 tree, 2 - D19 tree, 3 - B1 tree; 4 - B10 tree

Slika 5. Histogrami akustičnih odgovora: 1 - stablo A2, 2 - stablo D19, 3 - stablo B1, 4 - stablo B10

As one type histogram reflects the trees having different exterior, it is possible to conclude that there is no regular correlation between vibroacoustic response of a tree and its biomorphology. Most likely, greater influence is exercised by other parameters, e.g., macroor microstructure of wood, possible defects of trunk wood, etc. The role of genetic factors cannot be excluded either.
The analysis of vibroacoustic parameters energy response was carried out using the spectrogram in real time by defining the ratio of $\Delta S$ spectrum area square in $\Delta f$ band to $S_{o}$ total area of all the spectrum. Notably, in the total range of $0-10 \mathrm{kHz}$ frequencies, $\Delta S$ areas are considered in $\Delta f$ 0-2, 2-4, 4-6 and more than $6 \mathrm{kHz}$ ranges (Tab. 2).

According to Tab. 3, the trees have maximum value $\Delta S / S_{0}$ in the low frequency range more often, particularly, up to $2 \mathrm{kHz}$. Meanwhile, several samples have the maximum of this factor displaced towards higher frequencies, which is specific for trees A4, D1, D7, B2, B8 and B10.

The number of resonance peaks in the same frequency ranges is given in Tab. 4. It is obvious that D19 tree is the best in 'resonance' saturation, and A1 tree is the worst one.

Vibration absorption is a significant characteristic of wood acoustic properties. Research has shown that, in the range of $20-20000 \mathrm{~Hz}$, the vibration absorption changes from 50.4 up to $98.3 \mathrm{~dB} / \mathrm{m}$. One more prominent feature was revealed: the dispersion of separate trees values within the limits of a trial plot exceeded the dispersion of mean values received in total on these plots.

The common consistence pattern for all the trees includes the presence of minimum vibration absorption 
Table 3 Spectrum energy characteristics according to frequency ranges

Tablica 3. Obilježja energijskog spektra prema frekvencijskim rasponima

\begin{tabular}{|c|c|c|c|c|}
\hline \multirow[t]{2}{*}{$\begin{array}{l}\text { Tree index number } \\
\text { Oznaka uzorka stabla }\end{array}$} & \multicolumn{4}{|c|}{$\begin{array}{c}\Delta \boldsymbol{S} / \boldsymbol{S}_{\mathbf{0}} \text { values }(\%) \text { in a frequency range }(\mathbf{k H z}) \\
\Delta S / S_{0} \text { vrijednosti }(\%) \text { u frekvencijskom rasponu }(\mathrm{kHz})\end{array}$} \\
\hline & $0-2$ & $2-4$ & $4-6$ & more than 6 \\
\hline A1 & 61 & 24 & 11 & 4 \\
\hline A2 & 33 & 24 & 15 & 28 \\
\hline A4 & 13 & 27 & 9 & 51 \\
\hline A5 & 45 & 33 & 7 & 15 \\
\hline D1 & 32 & 22 & 22 & 24 \\
\hline D3 & 44 & 28 & 17 & 11 \\
\hline D7 & 30 & 20 & 19 & 31 \\
\hline D14 & 40 & 25 & 14 & 21 \\
\hline D17 & 38 & 29 & 13 & 20 \\
\hline D18 & 44 & 24 & 19 & 13 \\
\hline D19 & 31 & 25 & 15 & 29 \\
\hline $\mathrm{B} 1$ & 34 & 29 & 15 & 22 \\
\hline $\mathrm{B} 2$ & 25 & 24 & 19 & 37 \\
\hline B6 & 36 & 25 & 21 & 19 \\
\hline B8 & 29 & 21 & 20 & 30 \\
\hline $\mathrm{B} 10$ & 27 & 28 & 17 & 28 \\
\hline
\end{tabular}

Table 4 Distribution of the number of resonance peaks in frequency range $0 \div 10 \mathrm{kHz}$

Tablica 4. Raspodjela broja rezonantnih maksimuma u frekvencijskom području od 0 do $10 \mathrm{kHz}$

\begin{tabular}{|c|c|c|c|c|c|}
\hline \multirow{2}{*}{$\begin{array}{c}\text { Tree index } \\
\text { number } \\
\text { Oznaka uzorka } \\
\text { stabla }\end{array}$} & \multicolumn{3}{|c|}{$\begin{array}{c}\text { Number of peaks (pcs.) in frequency ranges (kHz) } \\
\text { Broj maksimuma u frekvencijskom rasponu (kHz) }\end{array}$} & $\begin{array}{c}\text { Total number of } \\
\text { peaks, pcs. } \\
\text { Ukupan broj } \\
\text { rezonantnih } \\
\text { maksimuma }\end{array}$ \\
\hline A1 & $0-2$ & $2-4$ & $4-6$ & 0 & 13 \\
\hline A2 & 5 & 5 & 3 & 6 & 21 \\
\hline A4 & 13 & 4 & 5 & 17 & 49 \\
\hline A5 & 8 & 9 & 10 & 1 & 16 \\
\hline D1 & 11 & 10 & 2 & 20 & 54 \\
\hline D3 & 9 & 6 & 7 & 12 & 31 \\
\hline D7 & 6 & 12 & 9 & 14 & 41 \\
\hline D14 & 10 & 10 & 13 & 17 & 49 \\
\hline D17 & 9 & 12 & 11 & 16 & 48 \\
\hline D18 & 9 & 11 & 10 & 30 & 46 \\
\hline D19 & 10 & 10 & 9 & 11 & 59 \\
\hline B1 & 8 & 8 & 5 & 20 & 32 \\
\hline B2 & 10 & 9 & 6 & 20 & 45 \\
\hline B6 & 15 & 12 & 8 & 20 & 55 \\
\hline B8 & 6 & 9 & 10 & 14 & 45 \\
\hline B10 & 7 & 10 & 10 & & 41 \\
\hline
\end{tabular}

in the area of basic resonance at frequencies of 600$1000 \mathrm{~Hz}$.

It is necessary to note that vibration absorption does not practically correlate with other acoustic parameters of a tree. For example, the best in relation to spectrum energy response D19 tree has no significant advantages against the worst A1 one. If compared with respect to vibration absorption, they yield 95.3 and $92.8 \mathrm{~dB} / \mathrm{m}$ accordingly.

The acoustic impedance was assessed within $\mathrm{Z}_{1}$ frequency range of $20-20000 \mathrm{~Hz}$, and within $\mathrm{Z}_{2}$ frequency band $\Delta f=800,1000 \mathrm{~Hz}$ as a parameter of ideal speed of impact power consumption. The results of the measurements are shown in Tab.5.
Tab. 5 shows, that there is no significant difference between the trees as far as acoustic impedance is concerned. The only exception is D19 tree, the impedance of which exceeds the average value of other trees in frequency band $\Delta f 800,1000 \mathrm{~Hz}$ almost 3 times.

\section{CONCLUSIONS}

5. ZAKLJUČAK

At the turn of the third millennium, scientists and experts of many countries are still trying to puzzle out 'the mystery of Stradivari', using for this purpose advanced technological solutions in the fields of physics, mathematics, chemistry, biology, etc. 
Table 5 Impedance values in different frequency ranges Tablica 5. Vrijednosti impedancije u različitim frekvencijskim rasponima

\begin{tabular}{|c|c|c|}
\hline \multirow{2}{*}{$\begin{array}{c}\text { Tree index } \\
\text { number } \\
\text { Oznaka uzorka } \\
\text { stabla }\end{array}$} & \multicolumn{2}{|c|}{$\begin{array}{c}\text { Impedance value, } \mathbf{1 0}^{\mathbf{4}} \mathbf{H} \cdot \mathbf{s} / \mathbf{m} \\
\text { Vrijednost impedancije, } 10^{4} \mathrm{H} \cdot \mathrm{s} / \mathrm{m}\end{array}$} \\
\hline & $Z_{1}$ & $Z_{2}$ \\
\hline $\mathrm{A} 1$ & 1.96 & 1.12 \\
\hline $\mathrm{A} 2$ & 1.86 & 1.24 \\
\hline A4 & 1.80 & 0.82 \\
\hline A5 & 1.52 & 0.80 \\
\hline A9 & 1.81 & 0.91 \\
\hline D1 & 2.34 & - \\
\hline D3 & 1.17 & 1.11 \\
\hline D7 & 2.04 & 0.70 \\
\hline D9 & 1.86 & 0.99 \\
\hline D14 & 2.04 & 0.94 \\
\hline D17 & 2.06 & 1.06 \\
\hline D18 & 1.92 & 0.94 \\
\hline D19 & 1.86 & 3.08 \\
\hline B1 & 1.80 & 0.53 \\
\hline B2 & 1.70 & 1.22 \\
\hline B3 & 1.50 & 0.96 \\
\hline B6 & 1.60 & 0.59 \\
\hline B8 & 1.70 & 0.53 \\
\hline $\mathrm{B} 10$ & 1.70 & - \\
\hline
\end{tabular}

It has been undoubtedly proved that one of the basic secrets of the great master's violin sounding is in the recognition of the proper material. Unfortunately, Stradivari, Amati, Guarneri and other great representatives of the Old Italian school did not leave any hints, but it has been recorded that they selected wood for the string-plate, the main sounding part of a violin, by tapping, and they designed an instrument judging from the 'sonority' factors known to them only. Using modern scientific terms, it is possible to ascertain that it was the professional skill of the master to decode the percussion-acoustic response of the source material that predetermined the quality of the product.

The results of the work done cannot claim to disclose any secrets in the field. For this purpose, significant complex research is necessary, both fundamental and applied, integrating the efforts of scientists and experts in different areas: physicists, acousticians, wood scientists, foresters and, the main thing, the recognized masters in the sphere of manufacturing corresponding musical instruments.

Meanwhile, we can limit ourselves to the following basic conclusions which, to a certain extent, can be an incentive for further shock-acoustic studies of standing spruce trees:

1. Trees have different vibroacoustic parameters even within the limits of one species and in similar environments;

2. However, not all vibroacoustic parameters represent practical interest during express-diagnostics and nondestructive selection of standing resonance raw material;
3. Amplitude-frequency analysis of vibroacoustic response in $1 / 3$ octave band gives maximal acoustic information on a tree;

4. In this respect, the presence of a resonance peak in the frequency range of $f \geq 2500 \mathrm{~Hz}$ determines wood acoustic characteristics;

5. It is possible to assess the quality of wood as potential resonance raw material by the form of the response spectral characteristics envelope in real time with sharply expressed basic resonance and presence of resonances in frequency band of $f>4 \mathrm{kHz}$;

6. There are real physical-theoretical preconditions and technical opportunities for creating a special compact device for express-diagnostics of acoustic quality and nondestructive selection of standing resonance raw material through the 'vibration shock' method.

\section{REFERENCES}

\section{LITERATURA}

1. Aleshchenko, O.; Kens, S.; Mergel, S., 2001: Experimental determination of physical and acoustic parameters of wood. S Kens; S. Mergel, O. Aleshchenko, O. UkrDLTU Scientific Bulletin, Issue 11.1, Lviv. 275 pp.

2. Bucur, V., 1983: An ultrasonic method for measuring the elastic constancy of wood increment cores bored from living trees. Ultrasonic, May, pp. 116-126.

3. Gladylin, A., 2000: Control of acoustic contact of ultrasound piezoelectric radiators with the object of influence. E-journal 'Investigated in Russia', 1-4: 943-947.

4. Goldsteins, A., 1975: Dependence of the speed of distribution of longitudinal pulse ultrasonic waves on geometrical dimensions of the samples of natural and polystyrene modified birch wood. Chemical modifying of wood, Riga, pp. 35-38.

5. Fedyukov, V. I.; Makaryeva, T. A., 1995: Tree as the system of orthogonal anisotropy of elastic properties and the opportunities of their diagnostics in nondestructive selection of standing resonance raw material. Proceedings of East-European acousticians association: Technical acoustics, 1 (2): 54-58.

6. Fedyukov, V. I.; Makaryeva, T. A., 1993: Research of the factors influencing the accuracy of measurements of physical-mechanical characteristics of resonance anisotropic materials as non-standard samples of core-samples: the report on R\&D / Mari Polytechnical Institute. ГР 01.9.70. 004852, Yoshkar-Ola, p. 26.

7. Yermolov, I. N.; Lunger, Yu. V., 2004: Nondestructive control: Reference Book: in 7 т. Ed. by V.V. Kluyeva. T.3: Ultrasound control, Moscow, Machinebuilding, 864 p.

\section{Corresponding address:}

Prof. VLADIMIR FEDYUKOV, Ph.D.

Forest-Engineering Faculty

Department of Standardization, Certification

and Merchandizing

Volga State University of Technology

Lenin Sq. 3

Yoshkar-Ola 424000, RUSSIA

e-mail: fiv48@mail.ru 